\title{
As redes têm centros: uma estratégia para migração da cultura pré- digital para a simbiose de redes sociais integradas em centros de atividades sociológicas e informacionais ${ }^{1}$
}

Gilson Lima*

Resumo Tentamos aqui responder a duas questões: 1) Como migrar uma qualificada herança da cultura, do saber e da pesquisa pré-digital para um aprendizado digital tendo em vista as novas gerações de gestores, pesquisadores, cientistas sociais e educadores? 2) Pensando no próprio aprendizado de ambientes digitais e no grande acúmulo de metodologias de pesquisa nas ciências sociais, que são, em grande parte, metodologias pré-digitais, como devemos proceder? Defenderemos a idéia da implantação de redes em estratégias integradas em uma concepção simbiótica (física e social), ou seja, redes enquanto Centros ampliados de Atividades Sociológicas e Informacionais. Para isso, abordaremos e precisaremos o conceito de informação e sua especificidade enquanto moderna informação computacional em redes digitais. Em seguida, apresentaremos a idéia de centro de atividades e demonstraremos algumas experiências sociais precursoras desses centros de atividade no Brasil.

Palavras chave pesquisa pré-digital, redes digitais, centros de atividades informacionais

\begin{abstract}
This article tries to answer two questions: 1) how to transfer a qualified heritage of culture, knowledge and pre-digital research to digital learning for the new generations of managers, researchers, social scientists and educators? 2) taking into account the digital learning and the great accumulation of research methodologies in the social sciences, largely pre-digital, how should we proceed? We defend the idea of installing networks in integrated strategies within a symbiotic conception, that is, networks as amplified centres of informational and sociological activities. We thus use the concept of information and its specificity as modern computational information in digital networks. We then present some of the social experiences which announce those centres of activities in Brazil.
\end{abstract}

Keywords pre-digital research, digital networks, centres of informational activities

\section{Introdução}

\footnotetext{
${ }^{1}$ Esse artigo é parte integrante e revisada de minha tese de doutoramento, intitulada: A reconstrução da realidade com a informação digital: a emergência da dupla competência sociológica, que foi apresentada e defendida em 2004 no Programa de Pós-Graduação em Sociologia da Universidade Federal do Rio Grande do Sul, como requisito parcial à obtenção do título de Doutor em Sociologia.
}

* Gilson Lima é doutor em Sociologia, Professor ProDoc do Programa de Pós Graduação em Sociologia da UFRGS, pesquisador e escritor. 
De tempos em tempos a humanidade se vê diante de desafios para migrar sua herança cultural e sua produção de conhecimento, cada vez mais complexa, para novas bases e suportes tecnológicos da inteligência, que desenvolvemos em determinados momentos históricos de nossa caminhada civilizatória. Certas tecnologias da inteligência causam impacto profundo e alteram significativamente o modo como produzimos e tratamos as informações e nossas outras diversas representações no mundo físico e social.

Foi justamente o que ocorreu quando as comunidades orais, que não dominavam a escrita, tiveram que migrar para uma complexa simbiose com a escrita impressa em átomos. É de conhecimento comum que a escrita não se confunde com o pensamento (isso reforça a afirmação de que uma nova cultura de reconstrução da realidade - cultura oral, sucedida pela escrita em átomos e, hoje, a cultura digital - não extingue as demais). O processo de implantação da escrita na história da civilização foi muito longo. No início, escrever significava aprender dezenas ou até centenas de sinais, o que não estava ao alcance de todos. A escrita em átomos utilizou-se de vários suportes: escrevia-se em pedras, em argila, em rolos vegetais oriundos do caule de uma planta (papiro) e, mais tarde, em pergaminhos, livros, etc.

Diversas civilizações orais mantinham sua memória por meio de histórias que se repetiam, preservando a herança civilizatória acumulada. A transmissão desta herança na cultura oral era seletiva: certas histórias eram fundamentais para uma determinada comunidade. As histórias quase sempre eram repetidas de geração a geração, sendo introduzidas nuanças e alguns detalhes de contextos existenciais em suas interpretações.

Sabemos que quando ainda não havia sido inventada a escrita e o alfabeto, nossa civilização exercia a reprodução da herança civilizatória apenas através de pensamentos e recordações.

Juntamente com o francês Regis Debray, afirmamos, recentemente, que somos seres biologicamente competentes para a comunicação oral, ou seja, a comunicação transmitida por palavras, imagens e signos. Possuímos, assim, toda uma organização genética: contamos com um aparelho respiratório munido de faringe e pregas vocais, que nos permitiu emitir sons e, posteriormente, conferir-lhes sentido e articular a fala. Entretanto, não somos seres biológicos ou geneticamente competentes para a escrita física suportada em átomos ou em bits ou em pixels. (LIMA, 2005, p. 72).

Antes mesmo da invenção da escrita e do alfabeto, os antigos já sabiam de algo que os cientistas mais modernos, da inteligência artificial, levaram muito tempo para descobrir, ou seja, o "cérebro" apresenta dificuldades para gravar informações e conhecimentos acumulados de uma geração para outra. Nosso "cérebro" não é um winchester que simplesmente grava algoritmos em bits e nunca mais os esquece.

Antes da invenção da escrita, os povos faziam uso de uma cultura informacional tomada por recursos exclusivamente orais e de memória cerebral e a cultura das civilizações orais dependia da capacidade de estocar e recuperar a sua memória civilizatória. Como a perenidade das tradições dependia quase que absolutamente da memória e dos registros cerebrais como locais de armazenamento do estoque coletivo de conhecimento, foi preciso inventar, então, técnicas de memorização artificial e de retórica para as conversas e histórias que não se queria esquecer. Os antigos criaram técnicas de reiteração e manuseio de dados e informações integrados a noções de tempo histórico-circular (reiteração constante: repetição + repetição = tradição). 
Muitas das histórias que ainda são contadas até hoje por nossos avós (heranças vivas que recebemos de nossos antepassados), são exemplos desses fluxos repetitivos de memórias orais que se movimentam pela nossa cultura civilizatória. Entretanto, é preciso lembrar que, posteriormente, tanto o tratamento dado ao estoque da informação impressa quanto o tratamento conferido à sua recuperação como dados e informações brutas, conviveu com o tratamento oral desses mesmos dados e informações durante toda a nossa existência e, convive até hoje, certamente, com o domínio da tecnologia dos registros físicos suportados em átomos.

Isso elucida a inconsistência de qualquer tentativa evolucionista ingênua de pretender tratar a determinação tecnológica separadamente da dimensão da cultura, ou seja, de levar em consideração, na história da informação, apenas a ótica da mera superação determinística das tecnologias de tratamento e armazenamento de informações.

Dificilmente, hoje, encontraremos uma investigação complexa de tratamento autônomo da informação oral que não utilize instrumentos ou anotações escritas ou que se restrinja a utilizar o próprio "cérebro" do investigador como o único recurso para estocar seus dados e registros.

Certamente, as pesquisas atuais de narrativas que envolvam registros de sons migram e emigram em simbioses com novos suportes de máquinas sensórias (gravadores, televisão, vídeos analógicos, etc.), para o devido encapsulamento da oralidade a ser posteriormente tratada e sistematizada, em geral, pela escrita linear.

A utilização dos recursos maquínicos sensórios (gravadores, rádios, vídeos), conferiu à oralidade nova significância na investigação científica, pois a maior fragilidade das tecnologias de tratamento oral da informação devia-se à sua dependência das capacidades de armazenamento cerebral. $\mathrm{O}$ uso desses novos recursos para o armazenamento dos fluxos orais permitiu que os cientistas sociais transformassem esses mesmos fluxos em bancos de dados com elevada independência do contexto gerador e, posteriormente, com uma forte dependência da escrita linear (transcrições) para a análise informacional.

No entanto, a escrita, mesmo em suportes físicos não eletrônicos, é um avanço técnico, não uma potencialidade genética como a fala. Foi por isso que, certamente, existiram sociedades sem domínio técnico da escrita. Em contraponto, não temos registros da existência de sociedades humanas que não tenham desenvolvido a comunicação oral. Justifica-se, assim, o fato de não precisarmos ir à escola para aprender a falar, mas, para a dominarmos a escrita, sim. Constatamos, desta forma, que somos seres biologicamente competentes para a comunicação oral e não somos seres biológica ou geneticamente competentes para a escrita em átomos, em bits ou em pixels. (LIMA, 2005, p. 71-84).

Com a escrita em átomos, o saber e o conhecimento puderam ser guardados e até transportados, isto é, deslocados geograficamente, sem requisitar a presença direta do autor das falas e nem mesmo do contexto em que um determinado texto original tivesse sido escrito - a informação conquista a pretensão de universalidade, transformando os conteúdos escritos em enunciados auto-suficientes e muito mais independentes, também, dos ambientes contextuais.

Quando tratamos da idéia de enunciados auto-suficientes, temos claro que mesmo concordando com sua existência efetiva, esses enunciados, por mais complexos que sejam, dependem de serem legitimados e compartilhados por uma comunidade de agentes de conhecimento, ou seja, de agentes capazes de significar e dar significação comum aos mesmos, seja por via interativa 
direta, seja por via indireta, como bem demonstrou Habermas em sua teoria consensual e procedimental da verdade. $^{2}$

A crítica da teoria consensual da verdade feita pelos defensores da teoria da verdade por correspondência (conceito $\Leftrightarrow$ realidade) ou dos substancialistas que defendem que um conceito preciso implica em fundamentações cujas determinações advêm de pré-disposições não interativas e não contextuais, não elimina que, em um determinado momento qualquer, o processo de legitimação ou de compartilhamento comum do sentido e da significação desses mesmos conceitos complexos foram compartilhados, legitimados e entendidos como expressões comuns de verdades por uma comunidade de conhecimento. Mesmo quando não ocorra o consenso na sua significação, os enunciados só podem se efetivar como processos de conflito quanto a legitimação do seu determinado entendimento comum numa comunidade de conhecimento cujos agentes sejam capazes de significar e compartilhar significados. Assim, para nós, a existência de enunciados auto-suficientes, com grande independência dos contextos interativos presenciais - uma conquista efetiva da escrita universalizante e objetiva - é real, mas sua existência não elimina um processo de legitimação e de compartilhamento comum da sua compreensão e significação pelos sujeitos e agentes da comunidade humana que produz e reproduz o conhecimento.

No entanto, a partir do domínio técnico da escrita, principalmente a alfabética, pela primeira vez na história da humanidade, pudemos estocar física e maciçamente enunciados, informações e conhecimentos para além da utilização do "cérebro" humano como único suporte disponível de memória de longo prazo. Para que isso ocorresse, criamos, também, um conjunto sistemático de técnicas, que permitiram tornar os enunciados auto-suficientes, viabilizando, assim, a leitura objetiva. Esse conjunto técnico de sistemas cartográficos auto-suficientes contribuiu, posteriormente, para que pudéssemos dobrar os textos em folhas finas de papel, para estruturálos e mantê-los articulados em linearidade (em linhas simétricas). Todas essas tecnologias auxiliares compõem o que alguns autores denominaram de aparelho artificial de leitura. (LEVY, 1993).

Inicialmente, após a invenção da escrita, a tradição oral como transmissora hereditária de cultura informacional manteve sua influência, visto que o processo de reprodução da escrita era manual e, por isso, muito lento. Nos mosteiros da Idade Média, o mestre era a autoridade responsável pela transmissão da cultura civilizatória. $\mathrm{O}$ acesso e a manipulação dos pergaminhos eram restritos aos mestres que, por sua autoridade, eram ungidos como informadores e socializadores do estoque de conhecimento civilizatório acumulado. Cabia-lhes, assim, pela sua autoridade, revelar a verdade.

Atualmente, estamos sofrendo o impacto da conquista da informação numérica em escala micro (um milhão de partes iguais em um metro) e em escala nanométrica (um bilhão de partes iguais em um metro). A humanidade está diante de um novo desafio de migração de sua cultura e da produção de conhecimento em suportes cada vez mais simbióticos e complexos, que exigem tratamentos também cada vez mais complexos e transdisciplinares da informação.

No entanto, a principal diferença agora é a velocidade. Em contraponto com os milhares de anos necessários para migrar e interagir entre as tecnologias de inteligência suportadas pela oralidade, desde que escrevemos em suportes físicos duros, como das paredes das grutas, da madeira, da argila, ao papiro, que permitiu o emprego do caniço, mais flexível e sutil, e ao pergaminho, que permitiu o uso de pluma de ganso, passagem crucial para o registro da cunha para a curva.

$2 \quad$ Ver Habermas (2000). 
Inventamos depois o papel, os blocos mais flexíveis de anotações e, assim, evoluímos da marreta que modulava os registros em pesados suportes como madeira e bronze, para escrevermos sutilmente em sedas e papel, usando a pena e a caneta. Depois, veio o alfabeto, o papel, o livro, as bibliotecas. Foram necessários milhares de anos para que, enfim, migrássemos de modo simbiótico, em cooperação e conflito, da cultura absoluta do tratamento oral da informação para a escrita moderna.

Hoje, ao contrariamente ao processo lento acima descrito, estamos sendo impelidos a migrar para novos suportes simbióticos de tratamento da informação, mas numa velocidade contada, no máximo, por décadas. É nesse sentido que defendemos uma estratégia complexa de migração e implantação do conhecimento acumulado, e da própria produção do conhecimento complexo pela humanidade, para os novos suportes informacionais nos espectros eletromagnéticos (bits, pixels) que conquistamos.

Para que essas questões possam ser superadas, é necessário que, por exemplo, a Sociologia passe por uma reformulação profunda frente uma abordagem transdisciplinar do social e de suas metodologias de tratamento informacional e, consequentemente, por uma aproximação mais simbiótica e intensa com a teoria e as aplicações da informação digital. ${ }^{3}$

Inicialmente, cabe esclarecer que entendemos por transdisciplinariedade não uma abordagem que compartilha uma perspectiva estrutural sistêmica integrada ao paradigma modernizador do racionalismo positivista, que busca simplesmente remapear as disciplinas científicas identificando novas expressões normativas dos territórios funcionais de competência. A perspectiva aqui explicitada se insere dentro do paradigma da complexidade, especificamente na abordagem de Edgar Morin (MORIN, 1996, p. 15-26).

Trata-se das diversas aptidões (reflexivas e/ou metodológicas) que todo e qualquer conhecimento complexo necessita para autoproduzir ciência contemporânea. A transdisciplinariedade aqui expressa deve implicar, certamente, numa competência mais vasta do que a presente na epistemologia clássica (monocompetência disciplinar), mas também não se restringe ao mero alargamento funcional e linear da monocompetência sociológica. Implica na mudança de arquétipo mental, no modo de ver e de compreender os fenômenos, uma mudança que, como afirma Edgar Morin, começa com a reforma do próprio pensamento (MORIN, 2000b).

Por que da insistência na transdisciplinaridade como uma múltipla competência informacional? Trata-se aqui de considerar a emergência da computação abstrata, na qual as relações societais e a própria análise e construção de conhecimento complexo estão cada vez mais envolvidas no processo de sintetização digital da realidade.

Isto significa que microprocessos sociais enlaçam-se continuamente em redes de informação e comunicação mais ou menos ampliadas e desdobradas por simulações de hiper-representação e reconstrução do mundo vital diante de uma coleção de suportes heterogêneos (softwares, rotinas digitais, máquinas cognitivas diversas), envolvendo manipulação complexa de bases de diferentes modalidades de dados numéricos, de imagens estáticas ou em movimento, de sons, de narrativas simetricamente estruturadas ou assimetricamente compostas, textos, documentos, ou seja, de dados brutos, primários ou secundários, que estão cada vez mais disponíveis e integrados a esse processo que denominamos sintetização digital da realidade.

\footnotetext{
${ }^{3}$ Para uma abordagem social da sociedade simbiogênica, ver Lima (2005).
} 
Vivemos numa sociedade em que o conhecimento, a sua produção e comunicação, assumem um papel cada vez mais central, resultando na necessidade de uma sociologia informacional e reflexiva para explicar uma realidade cada vez mais complexa: para isso, são necessárias novas modelações metódicas e metodológicas, também reflexivas. ${ }^{4}$

Essa reformulação transdisciplinar da sociologia não deve se ater apenas aos programas avançados de pós-graduação em Sociologia, mas deve estar presente desde a gênese da formação dos graduandos -as novas gerações de sociólogos- implicando novas integrações de conteúdos formativos e metodológicos em uma complexa aprendizagem investigativa.

Trata-se de iniciarmos um novo redesenho ainda mais radical nesse sentido, qual seja, o da perspectiva de produção e investigação sociológica de competência múltipla, tanto de domínio teórico, como aplicado também em ambientes estéticos, propícios à experimentação. De enfatizarmos, sobretudo, novos processos de aprendizagem e estímulos inovadores à descoberta de informações e de produção complexa de conhecimento. É preciso redirecionar o ensino da investigação e a produção de conhecimento, conferindo menos espaço ao consumo abstrato de teorias.

\section{Algumas palavras sobre o conceito de informação}

Quando pensamos em informações, lembramos de jornais e de notícias emitidas por redes de transmissão de rádio e de TV. Contudo, esse termo possui um percurso muito vago, seguido paralelamente de utilizações pragmáticas num universo técnico-instrumental. Também vemos, quase como natural, a existência, em nosso cotidiano, de informações provenientes de uma complexa logística de produção e transmissão de notícias, fatos, imagens e eventos capturados pelo tratamento de informações da mídia contemporânea. No entanto, essas informações possuem sentido e dele são carregadas, jamais podendo ocorrer independentemente da emissão de sentido. Ainda que alguns processos possam receber um tratamento material e ser tecnicamente desprovidos de sentido, o ciclo geral de transmissão e de conquistas da visibilidade de audiência no fluxo informacional midiático é, ao contrário, contaminado totalmente por sentidos.

A raiz da palavra informação é latina, informatio, não possuindo etimologia fundada na língua grega. Sendo assim, desde sua origem, o vocábulo está relacionado à idéia de forma, sendo entendido como correspondente a uma ação de modelar, ou seja, de dar forma simbiótica às coisas e aos fenômenos do mundo. No século XIII, porém, a palavra informação sofreu um acréscimo semântico, quando foi talhada pelo francês arcaico como enformer, que significa instruir. Assim, para um latino de influência francesa, informar passou a significar instruir, no sentido de educar, de dar forma ao espírito. Posteriormente, a partir do avanço das teorias contratualistas, o verbo informar passou a ter outro uso, tendo sido fortemente ligado ao universo do judiciário, de onde advém a máxima instruir um processo.( BRENTON, 1991, p. 49).

\footnotetext{
${ }^{4} \mathrm{O}$ primeiro livro de que tive conhecimento e que enfatiza uma intensa defesa de uma sociologia reflexiva, hoje tão em voga nas obas de sociólogos como Pierre Bourdieu, Zygmunt Bauman, Ulrich Beck, Scott Lasch e Anthony Giddens, e outros... é de autoria de Alvin W. Goudner, de Missouri, intitulado A crise da sociologia ocidental. Esse livro foi traduzido e publicado em Buenos Aires, Argentina, em 1970, pela Amorrortu.
} 
Neste trabalho, em primeiro lugar, é importante ter-se claro que estamos tratando de uma informação de tipo novo, ou seja, da noção de informação digital computada suportada em redes hipertextuais. ${ }^{5}$ A informação digital computada não apenas contém as características da informação oral e escrita, como amplifica-as, pois está vinculada a um novo tipo recursivo de processar, estocar e recuperar dados, sons e contextos. Referimo-nos, em suma, a um tipo específico da expressão informacional, diferente daquela que se encontra contida na abordagem da escrita impressa em átomos, que consolidou o pagus (a página estática) e que foi dotada de reprodução e seqüência linear.

O vocábulo latino pagus traz a idéia de campo, o campo onde o camponês pisa. Assim, dobramos a escrita de textos em folhas finas de papel, delimitadas vertical e horizontalmente, e organizamos esses textos, escrevendo em linhas, em sequiências cumulativas e por procedimentos hierárquicos, tal como conhecemos atualmente. Um texto pagus tem as seguintes características: 1) É um texto escrito em páginas estáticas, demarcadas fisicamente por um plano reto, do tipo tábua; 2) Tem um ciclo próprio (início, desenvolvimento e fim). É uma unidade isolada - um texto, um livro é uno, ou seja, uma unidade em si mesma; 3) A organização da sua narrativa é linear, como se seguíssemos uma linha, como se, cada vez mais, acumulássemos conhecimento numa seqüência progressiva enquanto caminhamos na imaginativa linha da leitura.

Para que a universalização do texto pagus e suas condicionantes da escrita e da leitura linear, seqüencial, cumulativa e hierárquica se efetivasse como tecnologia da inteligência dominante, foi preciso inventarmos todo um aparato artificial que conduzisse a leitura, quais sejam: os espaços em branco entre as palavras, a pontuação, as divisões de textos em parágrafos e capítulos, os índices, as notas de pé de página, etc..., até chegarmos às revistas, aos livros e às enciclopédias e obtermos uma complexa organização material e espacial responsável pela transmissão, produção e atualização do conhecimento escrito em átomos, que permitiu também a universalização da ciência e a ampliação de múltiplas instituições escolares.

A dominância do pagus sobre o pensamento implicou em duas grandes metodologias de reconstrução simbólica da realidade:

- A primeira é aquela que se subordinou à idéia de tempo, de precisão linear, presa ao conhecido cronos (tempo cronológico), ou seja, uma representação temporal que se tornou predominante, que pode ser comparada a uma flecha que se dirige permanentemente em uma direção progressiva e nunca mais reencontrará o seu início. Essa dominância nos impeliu para uma ruptura com a reiteração constante dos fluxos orais, uma perspectiva mais evolutiva e desenvolvimentista da representação e reconstrução do mundo (tempo flecha: repetição mais melhoria = progresso).

\footnotetext{
${ }^{5}$ Não foi possível especificar precisamente o conceito de hipertexto e sua diferenciação, complementação e suas novas implicações perante o império do pagus. Isso mereceria praticamente um novo artigo. Assim, lembraremos apenas que o criador da Internet, enquanto rede hipertextual, foi um físico e matemático Tim Berners-Lee. BernersLee criou, praticamente sozinho, e apresentou em 1980, a Web (Word Wide Web - a www é a interface gráfica da Internet). Com isso, inauguramos em larga escala a utilização do hipertexto. A Web é produto do casamento entre imaginação, informática e literatura. $\mathrm{O}$ jovem Tim incutiu, na sua precoce cabecinha, a idéia fixa de criar uma linguagem de comunicação, um protocolo que permitisse que qualquer coisa que pudéssemos imaginar pudesse também ser potencialmente conectada com qualquer coisa na rede, conseguindo, assim, a façanha da Web. De lá para cá, tornamo-nos navegadores desse info mar planetário. Entretanto, até hoje, Berners-Lee não foi lembrado para concorrer a um Prêmio Nobel.
} 
- A segunda metodologia foi a que acabou por levar-nos a um entendimento muito equivocado de inteligência e da memória humana. Até hoje, alguns cientistas pensam que nós transferimos mecanicamente, com a leitura, o estoque de informações que estava impresso nos documentos, para o "cérebro". Acreditam ainda que era assim que nos tornávamos inteligentes. Hoje, sabemos que esta é uma maneira muito primitiva da inteligência, conhecida como memória primária de longo prazo.

A informação oral, sem registro físico, não é e não foi capaz de alcançar a potencialidade da escrita. Através da universalização, a escrita linear impressa em átomos alcançou uma profunda potencialidade expressiva, que permitiu desvincular-se a leitura da informação (o acesso informacional) das amarras da dependência do seu contexto gerador, ou seja, do contexto presencial no qual essa própria informação tenha sido produzida. Mesmo assim, essa modalidade informacional não pode ser concebida sem a independência de sentido.

Seria demasiado injusto declarar que a informação oral sem registro físico não logrou historicamente domínios de tecnologias de memorização que permitissem dotá-la de reprodução, independentemente dos contextos presenciais geradores da informação. A constituição de fluxos orais repetitivos (como as histórias contadas por sábios narradores), por exemplo, sempre foi uma técnica utilizada pelas comunidades orais sem escrita para transmitirem sua herança civilizadora para outras gerações. Também nos mosteiros da Idade Média, ensinava-se retórica ${ }^{6}$ tendo em vista a precisão da reprodução oral, utilizando-se, para isso, muitas técnicas suplementares para a recuperação de informações transmitidas verbalmente, como a conexão de fluxos orais com indexação de termos ou definições decoradas ou até mesmo as conhecidas técnicas de memorização de lugares. ${ }^{7}$

É importante frisarmos que a reprodução de histórias levada a efeito apenas através de tecnologias de memorização (informação oral), sempre necessitava de um novo contexto presencial (narrador) para sua realização. Entre as implicações da dependência presencial, está a frágil memorização cerebral como único recurso de recuperação informacional, limitada, sobretudo, frente ao armazenamento de longo prazo, e a impossibilidade de expressão de modo independente de um novo contexto presencial, fatores que determinam, para a informação oral, como vimos, uma dinâmica circular e repetitiva (isso é mais explícito no caso dos fluxos orais repetitivos tomados como histórias, como estoque de informação).

A informação impressa em registros de átomos, ao contrário, conquista a universalidade, sendo independente do contexto presencial para sua reprodução e assumindo a característica totalizante. Contudo, seu tráfego é sempre dependente da dinâmica linear e, sobretudo, o sentido ou sentidos hermenêuticos múltiplos são inseparáveis de sua expressão formal.

Nos mosteiros da Idade Média, como vimos, os mestres constituíam a autoridade responsável pela transmissão da cultura civilizadora, e o acesso aos pergaminhos, lentamente transcritos

\footnotetext{
${ }^{6} \mathrm{O}$ ensino da retórica durante muito tempo abrangeu um ensinamento sistemático de técnicas de memorização e expressão oral para os narradores.

${ }^{7}$ Método dos lugares trata-se de uma conhecida técnica processual de memorização de longo prazo praticada pelos antigos narradores orais da antiguidade. Ela funciona utilizando-se de lugares conhecidos, isto é, de lugares já memorizados. Então, era necessário associar as idéias com os locais memorizados. Esse método combina a ordem de uma forma preestabelecida com uma associação que recorre a um sentido, visando, concretamente, a uma economia da recordação.
} 
manualmente, era restrito a esses guardiães, que, pela sua autoridade, possuíam a missão de revelar a verdade.

Com a invenção da impressão automática, os estudantes também passaram a ter, com muito mais facilidade, acesso ao estoque de conhecimento produzido pela humanidade e a co-participar da sua produção e armazenamento. Esse estoque foi sendo paulatinamente transferido para livros e enciclopédias, sendo que, conforme escreve o canadense McLuhan (1972), o mundo do saber nunca mais foi o mesmo após a impressão móvel difundida por Gutemberg. (MCLUHAN, 1992).

A informação digital computada não se restringe à que encontramos em livros tradicionais ou em impressões jornalísticas de conteúdos vinculados a suportes físicos (em átomos). Essa esfinge informacional tem como combustível central de sua realização específica um conceito de informação cuja principal especificidade constitui em dotar suas expressões, separando de um modo mais independente, nunca antes experimentado pela produção do conhecimento, o tratamento informacional da forma de seu sentido. (LIMA, 2005, p. 129-134).

Entendemos aqui por sentido a expansiva capacidade dos seres humanos de dotarem a realidade de representações simbólicas significantes e de compartilhar conexões e entendimentos de significados dessas representações comuns para si e, sobretudo, coletivamente, criando uma efetiva comunidade simbólica de conhecimento.

Poderíamos nos perguntar: o que é então a realidade? Weber e tantos outros pensadores nos ensinaram que realidade é a percepção compartilhada, a percepção social compartilhada é a realidade (WEBER, 1991). A realidade é produto de uma reconstrução social em simbiose do mundo e com as mentes que compartilham uma mesma conexão de sentido. Todavia, essa simbiose só pode ser profunda se ela romper com nossa concepção clássica do mundo físico, um todo objetivo, material e dado como estruturado, com uma ordem implícita a ser decifrada, como se o mundo fosse um grande mecanismo tomado por mecânicas explicações causais geradoras de diagnósticos fotográficos explicativos de sua "essência material".

Nobel Ilya Prigogine afirmou: o que quer que chamemos de realidade, ela só nos é revelada por intermédio de uma construção ativa na qual participamos. Isto pode ser entendido como uma verdade situada, ou como "contextualismo". Como também afirmou o pensador Merleau-Ponty "Uma vez que temos alguma idéia da verdade e que estamos dentro da verdade e não podemos sair dela, tudo o que posso fazer é definir uma verdade dentro da situação" (MERLEAUPONTY, 1960, p. 136-137). É a verdade situacional, e lembrando o filósofo Ortega y Gasset: "não há nenhum dizer que diga tudo o que dizer". Ou seja, ao dizer algo, dizemos apenas a possibilidade desse algo ser dito, dependemos, e muito, das circunstâncias de nossa limitada governabilidade situacional. A própria física quântica já nos demonstrou em laboratório que mesmo o mundo físico e natural só pode se encapsular em verdade, numa determinada situação, pela interferência estrutural do observador nos fenômenos do mundo que, com suas escolhas, inventa junto o mundo que observa. (ZOHAR, 1996).

Então, escrever e transmitir uma mensagem moderna implica em compartilharmos um ambiente imaginário comum, uma representação imaginária enquanto conexões e relações de sentido compartilhadas pelo contexto gerador dessa informação.

Porém, foi a possibilidade de tratar amplamente a forma da informação (o dado computável) de modo mais independente das criativas conexões humanas de sentidos compartilhadas, traduzindo-as em protocolos e operadores lógicos, que gerou um conhecimento e um tratamento 
autônomo e maquínico da informação, transformando-se, paulatinamente, em conhecimento técnico, inicialmente dominado por matemáticos e, depois, ganhando um contorno transdisciplinar. Deste pioneirismo, nós herdamos a maior parte das possibilidades modernas de comunicação à distância e de processamento automático da informação existente na atualidade.

Resumidamente, podemos entender por sentido de uma mensagem, para os fins que interessam ao presente artigo, um conjunto de significações interativas e compartilhadas entre emissor e receptor. A forma de uma mensagem, ao contrário, é o conjunto de símbolos e/ou sinais que podem ser processados independentemente de sua significação. Podemos exemplificar o elucidado através do telegrama. Para o funcionário da empresa de telégrafo, interessam apenas os símbolos necessários para que a mensagem seja transmitida. O que lhe importa é a finalidade de prestar o serviço. Esses símbolos serão posteriormente transformados em sinais telegráficos, que podem ser processados e transportados independentemente de sua significação; eles constituem a forma tomada pela mensagem.

A primeira ruptura que encontramos é entre o sentido e a forma que acompanha uma determinada mensagem. A segunda é a decomposição da forma de uma mensagem em símbolos e sinais. Os símbolos e os sinais permitem criar um suporte físico independente para o fluxo lógico da mensagem num espectro eletromagnético controlado.

É por isso que hoje vivemos uma corrida do ouro pela demarcação do invisível espaço público (quem é dono de quanto espaço) e com uma grande ausência e fragilidade dos Estados Nacionais Modernos. A história da busca por demarcações do mundo físico é longa. Inicialmente, correspondia à idéia de contornar uma extensão de terra com muros, fossos e outras barreiras, de modo a impedir o acesso indesejado de pessoas e animais. As delimitações passaram, assim, a colocar sob controle privado as terras, interrompendo qualquer direito à utilização que a comunidade tivesse anteriormente.

O movimento de delimitação realizou-se por diversos meios: através de leis promulgadas nos parlamentos; através de acordos entre todos os membros de uma mesma comunidade ou vila e através de licença concedida pelo rei. De algum tempo para cá, cada metro quadrado do planeta está demarcado e sob propriedade comercial privada ou sob o controle de algum governo - com exceção da Antártica que, por acordo internacional, foi parcialmente preservada como área comum inexplorável (RIFKIN, 1999, p. 43). A demarcação envolve, também, a comercialização de partes do oceano, da atmosfera e, mais recentemente, do espectro eletromagnético. As largas faixas de oceano - as águas costeiras - são comercialmente arrendadas, o mesmo ocorrendo com o ar, que foi convertido em corredores comerciais aéreos, e com as frequiências eletromagnéticas, concedidas pelos governos a empresas privadas para transmissões de rádio, telefone, televisão e processamento digital (computacional).

Retomando, a possibilidade de manipular com bastante flexibilidade os sinais se deve muito à descoberta de um matemático e físico francês, Joseph Fourier Fourier, que nos fez entender que qualquer elemento, por mais anárquico que seja, poderia ser representado por uma soma de funções matemáticas regulares e exprimíveis em termos de sinais elétricos com variações de quantidade x tempo, variações sinusoidais, ou seja, variações que apresentam curvas irregulares ou ondulantes de sentidos diferentes, variações de amplitudes e de fases. (BRENTON, 1991, p. $50)$.

A comunicação não oral é uma técnica que há muito tempo vem sendo dominada e aperfeiçoada pelas comunidades de vida. Porém, a teoria moderna da informação, muito mais do que a pura comunicação oral, é uma verdadeira reflexão sobre a economia do sinal, onde, a partir do estudo 
sobre sinais elétricos, definiu-se um suporte mensurável de precisão lógica de instruções e controles operadas num espectro eletromagnético.

Definitivamente, com a moderna informação numérica, deixamos para trás a época de comunicação à distância com sinais de fumaça, típica dos índios norte americanos, ou do ribombar dos tambores das tribos africanas e, até mesmo, a época das mensagens do telégrafo de Chappe. ${ }^{8}$ É da articulação entre sinal e símbolo que surgiu a moderna teoria da informação numérica. (LIMA, 2005, p. 124).

Os avanços obtidos pela moderna teoria da informação não teriam sido possíveis se não tivéssemos recebido, entre outras heranças, a invenção de uma álgebra um tanto particular do lógico e matemático inglês George Boole.

Ainda no Século XIX, George Boole, um matemático autodidata inglês, escreveu um livro com o título: An investigation of the laws of thought (Investigação das leis do pensamento), publicado em 1854, que foi muito apreciado. Meio século mais tarde, o matemático e filósofo Bertrand Russell satirizou Boole como o descobridor da "matemática pura". Boole perguntava-se se realmente existiam leis que regiam o pensamento. No livro An investigation of the laws of thought (BOOLE, 1958), ele responde a essa pergunta reduzindo a lógica do pensamento humano à operações matemáticas. Embora Boole não tenha explicado o pensamento humano, ele demonstrou o poder e a generalidade surpreendentes de uns poucos tipos simples de operações lógicas. Ele inventou um "protocolo" para descrever e manipular proposições lógicas e determinar se elas eram verdadeiras ou não. Essa "linguagem" hoje é chamada de álgebra booleana.

O termo linguagem foi colocado entre aspas de modo proposital, pois ele, como bem lembrou Fritjof Capra, somado à outras denominações do mundo tecnológico criadas pelos informaticistas, tem nos levado a uma boa dose de confusão. Isso ocorre pelo fato de os informaticistas usarem termos como "inteligência", "memória" e "linguagem" para descrever os recursos computacionais. Uma vez que essas expressões referem-se, primeiramente, a fenômenos humanos, tal nomenclatura pode induzir os cientistas a graves equívocos. A significância da inteligência consiste em se agir de maneira adequada quando um problema não é claramente definido e as soluções não são evidentes. Nessas situações, o comportamento humano inteligente baseia-se em práticas e reflexões existenciais acumuladas por meio de múltiplas experiências. A inexistência da capacidade de abstração, e as limitações intrínsecas às operações formais dos artefatos digitais, os tornam impossibilitados de serem dotados de inteligência. ${ }^{9}$

Quando os computadores folheiam as diversas páginas da WEB - através de interface humana eles não entendem o que essas páginas significam, apenas executam a transferência de lógicos conteúdos binários. ${ }^{10}$ A questão é: a linguagem humana está embutida numa teia de convenções sociais e culturais, a qual fornece um contexto de significados não-expressos em palavras. Os seres humanos entendem esse contexto porque ele faz parte de um "senso comum", mas um computador não pode ser programado para entender de modo complexo a linguagem e/ou dotado desse "senso comum". 11 As máquinas computáveis não têm sistema nervoso e muito menos a

\footnotetext{
${ }^{8}$ A invenção do telégrafo é rodeada de disputas pela sua autoria, assim como em muitas das histórias das invenções contadas pelos próprios cientistas. Nesse sentido ver: Rothman (2005).

${ }^{9}$ Cf. Capra (1998, p. 216).

${ }^{10}$ Ver Brockman (1997, p. 237-244).

${ }^{11}$ Cf. Winograd e Flores (1991. p. 107).
} 
misteriosa e complexa consciência dos mortais humanos, a não ser na imaginação da mídia especializada em difundir tecnologias.

É certo que os artefatos digitais desempenham funções indisponíveis em outros recursos automáticos, como o armazenamento de dados, textos, imagens, sons e hipertextos, podendo ainda se "comunicarem" entre si. Isso nos permite, cada vez mais, compartilharmos conhecimentos por meio de uma ou diversas e vastas redes digitais com seus permanentes fluxos de recuperação primária e de interação ambiental e simulações. Entretanto, as idéias, as soluções criativas, só podem ser obtidas por meio do pensamento, e não pelo computador.

Voltando a Boole, ele também desejava provar que as leis do pensamento humano podiam ser expressas por equações algébricas, como vimos anteriormente. Essas equações, imaginou ele, seriam usadas para descrever relações lógicas e, ao resolver as equações, qualquer pessoa poderia chegar à solução correta para o problema.

Cabe lembrarmos também uma obviedade: mesmo a própria lógica não foi dominada apenas pelos modernos. Por exemplo, na Idade Média, tida como obscurantista, a lógica servia somente para demonstrar os princípios teológicos fundamentais da existência de Deus, por exemplo. Nesse sentido, Boole (assim como tantos outros pensadores e cientistas), ofereceu uma grande contribuição para que se separasse a lógica do universo da filosofia e da teologia e a assentasse solidamente no universo da matemática.

Porém, o grande impulso teórico da moderna informação numérica computacional foi dado por Claude Shannon. Ele foi um dos grandes sistematizadores da moderna informação numérica e defendeu a aplicação da álgebra simbólica de Boole aos circuitos de comutação elétrica, em 1848, no seu clássico livro: Uma teoria matemática das comunicações.

Shannon, influenciado por Boole, enfatizou a relação existente entre esses operadores e os circuitos de comutações elétricas. Ou seja, pôs em evidência as possíveis relações entre o mundo dos símbolos e os dispositivos elétricos de transmissão de sinais. A teoria da informação nos forneceu uma medida de quantidade de dados, cuja unidade é o bit (Bynary Digit, um termo introduzido por Shannon). Para podermos pensar em processamento computável de informações, é necessário pensarmos, também, no seu protocolo ("linguagem”), ou seja, numa linguagem não humana, que consiste a base desse processamento. Shannon indicou que essa linguagem de máquina seria numérica, baseada em números binários: 0 (zero) e 1 (um), na qual cada 0 e cada 1 é chamado de bit.

Um dos aspectos essenciais da teoria da informação consiste em codificar, de modo eficaz, as mensagens transmitidas em presença de ruídos e de parasitas, com objetivo de transmiti-las com a maior rapidez possível e reconstituí-las corretamente, para quando chegarem ao seu destino. Shannon demonstrou que uma transmissão desse tipo é possível, através da criação de uma codificação de símbolos binários, que permitem que os sinais superem com eficácia problemas de ruído, obtendo, assim, um bom rendimento.

A invenção do processamento binário cruzou com as necessidades da criptografia, com os progressos do automatismo industrial e com as invenções da lógica moderna. Um dos pioneiros criadores do código binário, na verdade, foi o filósofo inglês Francis Bacon, mais conhecido pelos seus estudos sobre a importância da indução no processo de conhecimento. Ele desejava transmitir o pensamento à distância, e descobriu a importância da codificação binária ao cifrar mensagens diplomáticas secretas. 
No entanto, a partir da obra de Shannon, a moderna teoria da informação passou a dividir-se em duas vertentes, basicamente. A saber:

$1^{\text {a) }}$ A visão da informação em espectro eletromagnético como quantidade medida (bits) operada através de fórmulas criadas pelo austríaco Ludwig Boltzmann, e que tinham por objetivo medir a entropia dos gases.

$2^{\text {a }) ~ A ~ d e s i g n a c ̧ a ̃ o ~ d e ~ u m ~ s i ́ m b o l o ~ n u m e ́ r i c o ~(0 ~ o u ~ 1) ~ q u e ~ e ́ ~ c o d i f i c a d o ~ d e ~ m o d o ~ b i n a ́ r i o . ~ A ~}$ informação, neste último caso, designa uma medida e um símbolo. O moderno processamento automático da informação irá utilizar-se do termo informação computacional no sentido numérico binário (digital).

Foram essas duas vertentes, principalmente, que permitiram o pleno e frutífero encontro entre a técnica de codificação binária e o desenvolvimento teórico da álgebra lógica. George Boole, como vimos, inseriu a sua célebre álgebra lógica com a preocupação de melhorar a compreensão dos mecanismos da linguagem e das bases necessárias para a demonstração das verdades.

As funções lógicas da álgebra de Boole são notáveis em simplicidade e elegância. Elas permitem um processamento de todos os símbolos, incluindo os numéricos, permitindo que se realize operações aritméticas elementares. Mais tarde, partindo do processamento simbólico de Boole, foi possível criar um processamento automático da informação, integrando energia com lógica e convertendo a informação em um tipo complexo de energia: a energia informacional. O passo mais significativo neste sentido, ainda que inteiramente intelectual, foi a construção de uma máquina lógica, apropriada para a resolução de uma ampla gama de problemas lógicos e matemáticos: a célebre máquina de Turing.

Além dessa, foram inúmeras as contribuições que inauguraram a moderna informação computacional. No entanto, é válido destacar a grande contribuição do genial Alan Turing, um audacioso matemático inglês, proveniente da Universidade de Cambridge. Em 1936, ele escreveu sua dissertação, intitulada: Sobre os Números Computáveis. Ele desenvolveu, em seu texto, a idéia de uma hipotética máquina lógica, capaz de resolver problemas algoritmos, abrindo, com isso, o caminho para a criação posterior do processamento automático das informações.

A máquina de Turing - hipotética - consistia em uma fita de papel e um ponteiro que podia ler, escrever ou apagar um símbolo, deslocar a fita para a direita ou para a esquerda, marcar uma das casas do papel e parar. Essa máquina deveria ser capaz de resolver todos os problemas passíveis de serem formulados em termos de algoritmo. Partia-se da idéia de que a máquina tinha uma memória infinita. O único erro que não se devia cometer consistia em pensar ao realizar as operações. Este é o princípio básico da linguagem operacional das máquinas computacionais. Essa obediência automática é a base fundamental para a realização das instruções, e é o que garantirá a boa execução dos processamentos.

A máquina de Turing, na época uma "máquina" teórica, cujos propósitos eram também essencialmente teóricos, permitia reduzir as múltiplas possibilidades encontradas em processos finitos de instruções lógicas, traduzindo-os em conjuntos de problemas operacionais. Desse modo, nasceu com ele e se potencializou de modo mais preciso a noção de cômputo, a idéia de computar a realidade. Em suma, nasceu, com Turing, a era digital.

O que foi incubado com a máquina de Turing não foi apenas a idéia de uma máquina computacional ou uma complicada rede de impulsos elétricos ou um dispositivo por onde 
circulam estados distintos em um autômato de cálculos finitos, mas a idéia de um dispositivo que manipula e processa símbolos computáveis. Logo, o computador acabou por ser uma invenção pela qual se pretendeu imitar e simular os processos mentais conhecidos pela ciência, na época. ${ }^{12}$

A máquina de Turing mostrou os limites da lógica. Ou seja, Turing demonstrou a incapacidade de os números formalizados solucionarem alguns problemas reais. Demonstrou, também, que os princípios matemáticos e a lógica universal não abrangiam todas as situações. Entretanto, e mesmo assim, Turing ofereceu uma prova da força da pesquisa algorítmica. Ainda que sua teoria tivesse suposto uma máquina hipotética de processamento de algoritmo com uma memória infinita, Turing abriu o caminho para a implementação de uma máquina real, que realizasse de modo efetivo o processamento automático da informação.

$\mathrm{O}$ algoritmo tem origem árabe e o vocábulo significa restituição. Uma das propriedades da álgebra consiste em restituir uma igualdade quando se interfere nos termos da equação. Para os anglo-saxões, o algoritmo transformou-se "num processo efetivo". Mas é Alan Turing que irá dar-lhe uma forma definitiva: "Um algoritmo poderá ser definido como o conjunto completo das regras integradas a processos discretos (não contínuos) que permitem a resolução de um problema determinado". (BRENTON, 1991: 59).

A reunião da lógica binária de codificações complexas deu origem a várias linhagens de máquinas e processos lógicos autônomos. Isso implicou, na verdade, na criação de múltiplas famílias de autômatos, constituindo a emergência das máquinas cognitivas (computacionais) e o fim do monopólio da cognição realizada apenas pelos humanos, o que veio a causar a conseqüente e intensiva eliminação humana no mundo do trabalho na sociedade industrial. Esta eliminação ocorre cada vez mais em processos que envolvem simbioses musculares, sensórias, de cognição primária e até mesmo secundária, e em uma escala jamais experimentada na história da humanidade. Tudo isso vem implicando na urgente necessidade de inventarmos uma nova sociedade que não necessite de máquinas cognitivas humanas para o mercado de trabalho, de escolas e universidades que apenas fabriquem máquinas humanas cognitivas e, sobretudo, na necessidade de criarmos novos meios de acesso à renda e à vida econômica para além das atividades cognitivas disciplinares do mundo do trabalho industrial.

Enfim, os símbolos podem, agora, ser traduzidos em expressões formais, regradas, e interpretadas também por máquinas cognitivas. Turing fez o processamento sintático dos símbolos ser verdadeiramente maquinal, asseverando a universalidade potencial de sistemas simbólicos estritamente definidos. Por sua vez, o conceito de armazenamento de programas para computadores reafirmou a interpretabilidade dos símbolos já implícita na máquina de Turing. Todos esses conceitos já estavam disponíveis para serem implementados numa máquina efetiva quando, em pleno final da segunda grande guerra mundial, cientistas e matemáticos criaram o computador. $^{13}$

\footnotetext{
12 Infelizmente, muitos defensores da inteligência artificial e, até mesmo, das ciências cognitivas, ainda desconsideram os avanços já obtidos no campo da neurologia e seguem repetindo a gama de equívocos daqueles que insistem na idéia de uma mente humana computacional.

${ }^{13}$ Existe uma grande polêmica sobre o surgimento do primeiro computador. A polêmica vem desde o final do Século XVIII, quando da máquina analítica de madeira de Charles Babbage (1791-1871). Aqui não estamos interessados nessa polêmica, apenas queremos reiterar aqui que o ENIAC não era um computador e sim uma grande e sofisticada máquina de calcular para os padrões da época. Nesse sentido, mesmo reconhecendo a existência de máquinas recursivas anteriores à segunda guerra mundial, foi a partir da convergência de interesses militares e industriais, logo após a segunda grande guerra mundial, que efetivamente o computador se tornou uma máquina não experimental.
} 
Assim, a diferença mais significativa advinda da informação digital computada é a conquista quase definitiva da possibilidade de processarmos automaticamente tanto a forma como o sentido, dotando a análise e a própria construção do conhecimento de procedimentos recursivos cada vez mais complexos.

Foi somente quando tivemos acesso comercial ao computador que essa nova modalidade de informação, enquanto informação recursiva computada automaticamente, capaz de tratar o sentido e a forma de modo independente, se constituiu numa escala ampliada e passou a desempenhar um papel social importante. Assim, a partir da necessidade de distribuição de tarefas para o tratamento da informação computável, formou-se uma camada de especialistas escribas eletrônicos - que dominava o universo informacional específico, integrado por uma comunicação numérica composta de instruções e protocolos de algoritmos, traduzindo dados e eventos reais em um "simbolismo binário".

O grande impacto mais generalizado da informação computacional só se tornou possível quando da conquista de micro componentes, sobretudo os transistores, da miniaturização e o surgimento da micro informática. No entanto, a grande revolução social efetiva da informação digital ocorreu, de fato, com a criação daquilo que foi designado pela modesta palavrinha interface. Com a invenção das máquinas computacionais e sua humanização através de interfaces gráficas (pixels), bem como de seu processamento distribuído em descentralizadas micromáquinas, emerge uma nova cultura, ampliando, como nunca havia ocorrido antes, a camada da interface dos usuários amadores em detrimento do monopólio perital da programação maquínica (codificação algorítimica). É por isso que existe hoje a Web. Assim, somente quando se tornou possível construir uma integração entre cultura e interface é que emergiu a revolução da microinformática.

O Século XX conferiu uma velocidade ainda maior ao processamento da informação à distância. A invenção do cinema, do rádio, da TV, do transistor, do computador, do satélite e, mais tarde, da rede numérica mundial (a Internet e a WWW), etc. são apenas alguns dos exemplos mais significativos da extraordinária explosão tecnológica comunicacional e da importância da hipertextualização no mundo do conhecimento em que vivemos atualmente.

Vejamos a seguir uma estratégia de implantação que poderia ser efetivamente aplicada para solucionar e acelerar essa complexa demanda migratória da simbiose da cultura oral e da escrita em átomos para as redes hipertextuais integradas em espectros eletromagnéticos controlados.

\section{Constituição de centros de atividades sociológicas e informacionais ${ }^{14}$}

Se até o século $\mathrm{XX}$ vivemos uma era de descobertas de como entendemos e usamos as propriedades individuais de objetos tão diferentes como moléculas, aviões e sites, o século XXI está revelando ser o que permitirá estudarmos e descobrirmos como as

\footnotetext{
${ }^{14}$ As questões sobre a idéia de centro de atividades foram publicadas de modo mais didático em meu último e recente livro já citado, que se intitula Nômades de pedra: teoria da sociedade simbiogênica contada em prosas (LIMA, 2005). Ver principalmente: As redes têm centros: são centros de atividades sociológicas e informacionais, p. 249-259.
} 
propriedades individuais de todos esses objetos e fenômenos se relacionam.

Pensamos que uma abordagem aplicada importante para enfrentarmos a implantação de projetos de múltipla competência sociológica em redes hipertextuais pode ser encontrada por meio do uso adequado da Teoria de redes em base de grafos, ${ }^{15}$ que aponta para constituição no interior dessas redes, de Centros de Atividades. Vejamos, então, o que seria um centro de atividades em agregações complexas de redes.

Começaremos descrevendo um rápido caso. Em fevereiro de 2000, um hacker conhecido pelo apelido de MafiaBoy conseguiu paralisar alguns dos maiores sites do mundo, incluindo Yahoo, Amazon e eBay, causando caos em toda a Internet, principalmente nos Estados Unidos. $\mathrm{O}$ ataque mobilizou o FBI, que saiu em busca daquele que havia derrotado empresas que contam com os melhores especialistas em segurança do mundo. Parecia trabalho de profissional. Ocorreu que acabaram chegando a um garoto canadense, de quinze anos de idade, que, da casa dos seus pais, comandou o ataque. $\mathrm{O}$ ataque, idealizado e posto em prática por um amador, foi realizado com softwares gratuitos que estão a pouca distância de qualquer um que tenha uma conexão com a Internet. Isso demonstra que mesmo uma rede de agregação complexa como a World Wide Web é capaz de absorver facilmente falhas aleatórias, como um site que sai do ar, mas está fadada ao desastre se tiver de enfrentar um ataque dirigido.

A dificuldade está justamente em uma peculiaridade das redes, descoberta por MafiaBoy. Se realizarmos uma simulação num computador sobre os links da Web, veremos que alguns poucos sites (como Amazon, Yahoo e eBay) funcionam como centros de atividade. Encontraremos milhares de outras páginas da Internet apontando para elas e milhares de pessoas tentando acessar esses sites ao mesmo tempo. Tirar algumas delas do ar, como fez o MafiaBoy, simplesmente paralisa a rede.

Esse caso gerou uma série de estudos sobre outros fenômenos de redes de agregação aleatória, com tentativas de encontrar, nessas redes, a existência, ou não, de centros de atividade. Descobriu-se, inclusive, que as redes e seus centros de atividades existem em toda parte no mundo contemporâneo, governando desde os relacionamentos humanos até a forma como as moléculas do nosso corpo se ligam.

Usamos essas redes o tempo todo, às vezes sem perceber, como, por exemplo, quando vamos a um aeroporto e subimos em um avião. Se, durante uma viagem longa, folhearmos uma revista de bordo, provavelmente notaremos, em uma de suas páginas, que ela discrimina todos os vôos da companhia aérea em que estamos voando. Se repararmos na quantidade de linhas aéreas que conectam uma cidade à outra, veremos que a grande maioria dos aeroportos têm um número pequeno de aviões saindo ou chegando, enquanto alguns outros poucos, recebem uma tamanha variedade de linhas, que se torna difícil entender o mapa. No caso do Brasil, são os aeroportos de São Paulo e do Rio de Janeiro que funcionam como centros de atividade. O Brasil provavelmente não sofreria grandes danos se alguns aeroportos de pouco movimento fechassem

$15 \quad$ A teoria e técnica estatística de grafos é o ramo da matemática que estuda as propriedades de grafos. Um grafo é uma derivação da Matemática expressa num conjunto de pontos, chamados vértices (ou nodos), conectados por linhas, denominadas arestas (ou arcos). Dependendo da aplicação, as arestas podem ter ou não direção, podem ou não ligar as arestas a um vértice e a ele próprio. Os vértices, as arestas podem ou não ter um peso (numérico) associado às relações. Se as arestas têm uma direção associada (indicada por uma seta na representação gráfica), temos um grafo direcionado ou digrafo. 
por um dia. No entanto, parar simultaneamente os aeroportos do Rio e de São Paulo paralisaria quase todo o sistema aéreo brasileiro. O mesmo vale, virtualmente, para qualquer país: em todos eles há pontos estratégicos na rede aérea que, se atacados, gerariam um colapso.

Um estudo que se tornou muito conhecido e foi publicado em livro, foi o do jornalista Malcolm Gladwell, da revista americana The New Yorker, sob o nome de O Ponto de Desequilíbrio (GLADWELL, 2002). Gladwell analisou, nesse livro, a habilidade de pessoas de diferentes grupos sociais para estabelecerem relações pessoais e observou que cada grupo possuía apenas algumas pessoas com muitos amigos e conhecidos. Essas pessoas agem como os centros de atividade, também conhecidos como conectores. Ainda nesse sentido, os cientistas constataram que a própria natureza segue essas mesmas leis das redes criadas pelos homens com conectores, que são nós com um número anomalamente grande de links e que estão presentes em vários sistemas complexos, desde a pequena célula viva até a macro organização das sociedades humanas (BARABÃSI, 2002).

Conforme postula Albert-Lászlo Barabãsi, o corpo humano também é dominado por esses centros de atividades. Possuímos algumas poucas moléculas que participam de muitas atividades. O caso da proteína $p 53$ é exemplar. Ela é a responsável por garantir a ordem dentro das células do nosso corpo. Impede, por exemplo, que células se multipliquem descontroladamente, iniciando o processo que pode levar a um câncer. Cerca de $50 \%$ dos cânceres humanos têm relação com uma mutação no gene que fabrica a $p 53$. Na célula, o desempenho quase não é afetado pela remoção acidental de uma proteína qualquer - assim como uma falha num site obscuro não traria consequiências sérias à Internet. Mas um ataque no lugar certo pode ser fatal. Como afirmam os descobridores do gene, David Lane e Arthur Levine, a forma mais efetiva de destruir essa rede é atacar as proteínas mais conectadas, a $p 53$ é uma delas, e uma mutação nela vai interromper algumas funções básicas da célula (BARABÃ SI, 2002: 47$52)$.

Há mais de 50 anos que matemáticos estão discutindo a possibilidade de que as redes formem-se por agregações aleatórias e de que elas constituam-se também totalmente ao acaso. Existem autores matemáticos que optaram pela opinião de que existe uma indeterminação absoluta e descentrada das agregações aleatórias e complexas nas redes. Na Matemática, por exemplo, os estudiosos que privilegiaram o acaso na estruturação das redes aleatórias criaram belíssimas fórmulas, pois seu interesse estava mais voltado à expressão da beleza da Matemática do que à obtenção de uma compreensão profunda das estruturações das redes. Alguns estudiosos, no mesmo caminho desses matemáticos, encantados com as agregações aleatórias das redes, estudaram e buscaram suas expressões e manifestações em fenômenos sociais e da natureza. Aqui nos parece que é por onde transita o livro de Steven Johson (2003) Emergência: $a$ dinâmica de rede em formigas, cérebros, cidades e softwares.

No final desse livro, Johnson confessa que, de certo modo, a idéia de escrevê-lo surgiu com um presente que ganhou de aniversário de 30 anos: um atlas de grande formato da cidade de Hamburgo, que tinha uma espantosa semelhança com um corte de perfil de um "cérebro" humano. Johnson faz toda a trajetória de seu livro encantado com a complexidade do modo aleatório da estruturação emergente das redes complexas, que reafirmam a tese da organização emergente, na qual a beleza da auto-organização é produto de uma complexidade tipo botton-up, ou seja, agentes individuais que residem numa escala baixa começam a produzir comportamentos que irão residir em uma escala acima deles: sejam formigas que criam colônias, sejam cidadãos que criam comunidades e cidades, sejam softwares que criam recursos de apoio cognitivo aos seus usuários. 
Johnson, que já havia se fascinado pelas agregações aleatórias em alguns estudos, como, por exemplo, o do primitivo Dictyostelium discoideum, estudado principalmente por Evelyn Fox Keller e Lee Segel, que mostra a beleza estética da Matemática aplicada ao estudo de seres vivos, resolveu também tentar decifrar a emergência aleatória das relações em redes evoluindo, a partir de uma sopa primordial, em direção a uma nova camada de complexidade e sem um comando centralizado de líderes em diferentes fenômenos, desde aglomerações de pixels brilhantes em uma tela de computador, nas conexões de sinapses da mente, nos fluxos de aglomerados de cidades humanas, até a organização dos formigueiros (JOHNSON, 2003, p. 215). No entanto, pensamos que a vibração de Johnson pela beleza das agregações aleatórias o impediu de ver que, nos processos de relações em rede, existem também centros de atividades, que estão presentes nos formigueiros, nos "cérebros" humanos, nas cidades, nos softwares e até mesmo nos pixels brilhantes da tela do computador. Não deixamos de concordar com a complexidade proposta por Johnson, mas questionamos a idéia da existência de associação aleatória absoluta presente na sua visão de complexidade.

Atualmente, os estudos de relacionamentos em redes têm demonstrado que essas diversas redes seguem o fenômeno da impressão de que o mundo é pequeno - uma frase que se diz quando encontramos uma pessoa pela primeira vez num lugar inesperado e descobrimos que ela é amiga de um amigo nosso. Segundo cálculos de Albert-Lászlo Barabãsi, uma página da Web está a somente 19 cliques de qualquer outra, ainda que uma seja sediada no Japão e a outra em Honduras (BARABÃSI, 2002: 36). A explicação para o fenômeno é simples: preferimos nos conectar ao que já é mais conectado. Páginas da Web com mais links têm também uma chance maior de receberem ainda mais links, pois já são conhecidas. Atores de Hollywood que já participaram de vários filmes têm mais probabilidades de fazerem novos filmes. Hoje está provado que, independentemente de ser uma rede de computadores, moléculas ou pessoas, a popularidade atrai. As descobertas de Barabãsi e seus colegas sobre redes são parte de uma revolução que vai mudar nosso entendimento do mundo.

Se até o século $\mathrm{XX}$ vivemos uma era de descobertas de como entendemos e usamos as propriedades individuais de objetos tão diferentes como moléculas, aviões e sites, o século XXI está revelando ser o que permitirá estudarmos e descobrirmos como as propriedades individuais de todos esses objetos e fenômenos se relacionam.

A existência de poucos sites, moléculas e aeroportos que funcionam como centros de atividades, abre espaço para estudos novos sobre a interação entre cada um dos componentes das redes sociais e a vida em sociedade. Por exemplo, as pesquisas sobre epidemias sociais têm demonstrado que a rede de relações sexuais funciona dentro do mesmo padrão de centros de atividade. Nela, alguns poucos têm centenas de parceiros sexuais (conectores), enquanto a maioria tem relações sexuais somente com uma ou outra pessoa. No caso de uma doença sexualmente transmissível, são os conectores os primeiros a serem infectados e também são eles os responsáveis por disseminar a doença para muitas outras pessoas. Agora, pensemos na AIDS.

Não dispusemos, hoje, de remédio suficiente para tratar todos os soro-positivos do mundo. Então, o que é mais eficiente? Cuidar de mulheres grávidas ou tratar das pessoas com muitos parceiros sexuais? Gladwell, afirma que a dura resposta a essa pergunta pode ser demonstrada matematicamente, mas que devemos, prioritariamente, tratar primeiro os agentes irradiadores da epidemia, pois isso derrubaria a carga virótica da sociedade, diminuindo a transmissibilidade, brecando a disseminação da Aids (GLADWELL, 2002, p. 22-24).

Essas descobertas todas ocorreram por dois motivos: o primeiro é que somente nas últimas décadas surgiram computadores de mesa a preços acessíveis, capazes de dar conta da enorme 
demanda de cálculos necessários para se entender o que se passa dentro das redes. Antes disso, até se sabia que as redes existiam, mas era impossível entendê-las, dada sua complexidade; o segundo, como já dissemos, é a própria Matemática, que nos auxilia para entendermos os atratores das redes, por meio de operações de cálculos relacionais, que constituem o campo da matemática conhecido como grafos.

Grafos são redes que consistem em nós conectados por arestas ou arcos. Em grafos direcionados, as conexões entre os nós são direcionais e chamadas de arcos. Em grafos não-direcionais, as conexões chamam-se arestas. Aqui estamos falando, principalmente, de grafos direcionados. Quando criamos algoritmos aplicáveis a grafos, queremos encontrar um caminho entre dois nós, encontrar o caminho mais curto entre dois nós. Permitindo identificar a determinação de ciclos em grafos (um ciclo, no grafo, é um caminho não vazio de um nó a outro), busca-se encontrar um caminho que alcance todos os nós. Freqüentemente, os nós ou arcos de um grafo têm pesos ou custos associados a eles e, geralmente, estamos interessados em encontrar o caminho mais barato.

Já existe uma literatura consistente sobre algoritmos para grafos, que são uma parte importante da matemática discreta. Grafos também são muito úteis no estudo de algoritmos computacionais, o que não nos interessa neste artigo. Interessa-nos, apenas, dizer que para uma análise de agregação complexa em redes, faz-se necessário estabelecermos relações entre os dados criando, no mínimo, um dicionário cujas chaves são os nós do grafo.

Em vista disso, a partir de uma rápida mineração pela $W e b$, encontramos, sem muito esforço, alguns centros de atividade em dupla competência na sociologia (sociologia e informática) ${ }^{16}$ no Brasil, alguns mais ativos, outros menos. Vamos alguns dos exemplos encontrados:

Na Unicamp encontramos o Portal de Ciências Sociais e Sociedade da Informação, que, conforme seus registros, opera como um centro de atividade de integração de cursos, conferências, listas de discussão, bibliotecas virtuais, legislação e pesquisas e que relaciona as ciências sociais com múltiplos temas informacionais, inclusive temas especializados, como o uso da inteligência artificial nas ciências sociais integrada a cursos, oficinas e laboratórios (UNICAMP, 2005).

Outro exemplo de um centro de atividade de dupla competência em Sociologia e Ciências Sociais encontramos no Iuperj, que se caracteriza por migrar as linhas de trabalho consolidadas a partir de extensa produção acadêmica tradicional ao que os pesquisadores desse centro de atividade denominaram de Programa Institutos Virtuais, que é também patrocinado pela Fundação de Amparo à Pesquisa do Estado do Rio de Janeiro - Faperj. Os pesquisadores do Iuperj possuem também um grande número de softwares integrados à pesquisa, principalmente softwares de análise quantitativa, como o SPSS, e possuem também alguns bancos de dados significativos: Bancos de Dados Bibliográficos e Políticos como: a) Urbandata; b) Data Índice; c) Doxa - Laboratório de Pesquisas em Comunicação Política e Opinião Pública; d) Dados Eleitorais do Brasil (IUPERJ, 2005).

\footnotetext{
${ }^{16}$ Compreendendo a idéia de competência em termos complexos e não neo-positivistas, como já afirmamos, e entendendo também que os microprocessos sociais contemporâneos entrelaçam-se cada vez mais continuamente em redes de informação e comunicação mais ou menos ampliadas e desdobradas por simulações de hiper-representação e reconstrução do mundo vital diante de uma coleção de suportes heterogêneos (softwares, rotinas digitais, máquinas cognitivas diversas), chamamos de dupla competência sociológica a pesquisa, o saber e o aprendizado sociológico integrados à uma sociologia da informação, ou seja, a competência sociológica integrada a competência informacional.
} 
Um outro importante exemplo de centro de atividades em dupla competência que encontramos está na Universidade Federal de Minas Gerais. Encontramos nessa Universidade um centro de atividade conhecido como Crisp - Centro de Estudos de Criminalidade e Segurança Pública (UNIVERSIDADE FEDERAL DE MINAS GERAIS, 2005).

Esse centro é um órgão voltado para a elaboração, acompanhamento de implementação e avaliação crítica de políticas públicas na área da justiça criminal. Ligado à Universidade Federal de Minas Gerais (UFMG), o Crisp é composto por pesquisadores dessa Universidade e de órgãos públicos envolvidos no combate à criminalidade, que visa facilitar ativamente a qualificação dos profissionais da área de segurança pública, elaborar estudos e pesquisas aplicadas e metodológicas, de alta qualidade técnica, que procurem enfocar problemas e questões de interesse para o combate à criminalidade. Outra característica das atividades do Crisp é a organização de bases de dados criminais de interesse para as organizações da justiça criminal brasileira.

Merece destaque a organização de dados pontuais sobre crimes na cidade de Belo Horizonte, que se constituiu em iniciativa inédita no Brasil e se tornou referência em análises espaciais de dupla competência sobre a criminalidade e no mapeamento de crimes. Nos últimos anos, o Crisp tornou-se um centro de atividades com um papel muito importante enquanto órgão de assessoria, de suporte técnico e acadêmico, e de formação para organizações do sistema de justiça criminal.

O Crisp realizou alguns importantes e inovadores produtos informacionais derivados da dupla competência sociológica como:

a)Atlas da criminalidade de Belo Horizonte - diagnósticos, perspectivas e sugestões de programas de controle.

b) Atlas da criminalidade de Minas Gerais.

c) Diagnóstico da criminalidade violenta na região metropolitana de Belo Horizonte : estudo espaço-temporal do período 1986 - 2001.

d) Organização de base de dados para a delegacia de crimes contra a vida.

e) As implicações socioeconômicas da violência em Belo Horizonte:os centros de saúde conselhos comunitários de segurança pública: avaliação, análise e acompanhamento do policiamento comunitário em Belo Horizonte.

f) Mapa da distribuição e uso de drogas em Minas Gerais.

g) Análise do fluxo das ocorrências de homicídio no Sistema de Justiça.

h) Pesquisa de vitimização em Belo Horizonte.

i) As implicações socioeconômicas da violência em Belo Horizonte: as escolas de Belo Horizonte.

j) Criação de uma biblioteca de sub-rotinas de análise estatística integrada ao Sistema de Informação da PM/MG.

1) Análise no efeito do tamanho das cidades no comportamento das taxas de crime no Estado de Minas Gerais. 
m) Detecção de clusters (agregação de dados-fenômenos).

n) Software bayes.

A força significante deste centro de atividade em dupla competência é a utilização, nos trabalhos de pesquisa, do software bayes. Esse programa permite um suporte informacional e mimético espacial utilizando mapas com o método empírico bayesiano, que integra diferentes taxas desconhecidas, derivadas de processos sociais e ambientais subjacentes, que afetam a região em estudo. Dessa forma, é possível, mediante modelos probabilísticos, determinar as variações das taxas de crime. Essa modelagem das taxas desconhecidas não são números totalmente arbitrários, mas possuem grandes relações com os dados históricos. Assim, algumas áreas com elevadas taxas devidas meramente a uma flutuação aleatória, são 'estabilizadas' para um valor mais plausível (taxa global) pelo estimador bayesiano linear empírico ótimo.

Esse centro de atividades também disponibiliza alguns de seus cursos em plataformas para educação à distância, com apoio de redes Web. Utiliza-se, ainda, de vídeos-aula e outros recursos de apoio aos cursos à distância.

Por fim, encontramos, nesse centro de atividade, também um volumoso banco em base de dados sobre "Homicídios no Brasil" - "Atlas Brasil". A base de dados do projeto possui como unidade de análise os municípios brasileiros. Contém a relação dessas localidades com seus respectivos números brutos de homicídios, as taxas corrigidas e a população para o período compreendido entre 1980 e 2000.

O principal objetivo desse banco de dados é possibilitar a análise da distribuição dos homicídios no Brasil levando em conta as taxas de homicídio relacionadas com o tamanho populacional dos municípios, os tipos de armas utilizadas pelos agressores e o perfil das vítimas, considerando variáveis como raça, instrução, sexo, estado civil, faixa etária e local onde ocorreu o crime.

Esse banco foi provido também de dados secundários, do Datasus - banco de dados construído pelo Sistema Único de Saúde -, bem como informações do IBGE - Instituto Brasileiro de Geografia e Estatística. No Datasus, foram coletados os números brutos de homicídios registrados no Brasil, não tendo sido feitas as distinções entre homicídios culposos e dolosos, enquanto as informações do IBGE referem-se ao levantamento das micro e mesoregiões, municípios e estados.

Para o cálculo das taxas de homicídios é utilizada também a chamada Taxa Bayesiana ou Taxa Corrigida, que estabelece um compromisso entre a informação da taxa bruta da área e a informação da taxa geral da região a que pertence essa área (a área e suas vizinhanças).

Um último exemplo da existência de centros de atividade em dupla competência que gostaríamos de destacar é a Fundação de Economia e Estatística (FEE) no Rio Grande do Sul. Trata-se de uma instituição na qual há uma larga cultura de tratamento informacional quantitativo e que dispõe de uma vasta biblioteca virtual, onde se pode encontrar sua produção de índices, mapas e dados que podem ser acessados em CDs, Teses, Documentos diversos, Boletins, Carta de Conjuntura, Informe PED (mensal), Informe PED (anual), IMCV, Revistas (Ensaios FEE, Indicadores Econômicos FEE, Mulher e Trabalho, Metrópoles: enfoque sobre a problemática habitacional).

A FEE, enquanto centro de atividade em dupla competência informacional, também disponibiliza diferentes produtos estatísticos, tais como o Índice de Desenvolvimento Socioeconômico (Idese) - Rio Grande do Sul. O Idese do Estado, em 2001, é praticamente o 
mesmo de 2000, com crescimento no bloco de Educação compensado por quedas nos blocos de Renda e Saúde. Também se encontram atualizações sistemáticas de dados sobre PIB, População, Emprego/Desemprego, bem como o Indicador Mensal do Comércio Varejista - IMCV (Desempenho do varejo sinaliza crescimento nas vendas).

Encontramos também no site da FEE uma Biblioteca Virtual do Rio Grande do Sul (BVRS). Trata-se de uma Rede de Bibliotecas do setor público do Estado do Rio Grande do Sul, administrada pela Fundação de Economia e Estatística (FEE). Nela, o usuário acessa múltiplos dados bibliográficos e realiza pesquisas usando nome de autores e títulos ou assuntos, podendo percorrer apenas uma, ou percorrendo todas as bibliotecas integradas. É também possível baixar registros bibliográficos (downloads) para formação de bases de dados locais, desde que as bases utilizem o padrão CDS/ISIS e o formato MARC (FUNDAÇÃO DE ECONOMIA E ESTATÍSTICA, 2005).

Esses exemplos se prestam a indicar que é possível, numa rápida mineração pela Internet, encontramos alguns poucos, porém expressivos, centros de atividade em dupla competência em Sociologia e Ciências Sociais no Brasil. Certamente podemos acelerar ainda mais a migração da cultura pré-digital do saber social para uma efetiva simbiose digital, sem perdermos a dimensão complexa tão necessária para o conhecimento - em nosso caso, o conhecimento sociológico - se qualificarmos a estratégia de implantação de centros de atividades sociológicas e informacionais.

A escolha desses exemplos foi mais ou menos aleatória e tem a intenção de demonstrar o potencial dessa abordagem estratégica. A concepção de um centro de atividades sociológicas e informacionais leva em consideração não apenas a integração e conexões físicas e eletrônicas da implantação de uma rede, seja ela temática, formativa ou informativa. Certamente que, nesse sentido, não se trata apenas de publicarmos páginas na Web e, sim, de levarmos em consideração toda a teia de relações, integrações, cooperações e atividades sociais que envolvem um centro de atividades. Trata-se de um nódulo central, gerador de múltiplas interações físicas e sociais capazes de incidir e potencializar ainda mais a cultura simbiótica da informação computacional. Nem todas as iniciativas de integração a Web devem ser entendidas como centros de atividades, mas quando estamos tratando de um projeto de porte médio ou grande, com agregações em redes reflexivas, pensamos que a idéia de constituirmos centros de atividade é muito mais potente do que a de "sistemas informacionais integrados em ambientes digitais".

Queremos contrapor nossa abordagem com a perspectiva de uma concepção de cunho "neopositivista", tão compartilhada por Luhmann em sua cibernetização sistêmica reducionista aplicada aos fenômenos da vida em sociedade. ${ }^{17}$ Os sistemistas restringem a construção do conhecimento e da comunicação devido a seu método de encapsulamento dos conteúdos e interações, ou melhor, dos procedimentos lógico-formais da computação abstrata. Essa visão esconde um conceito pobre e limitado de conhecimento, restringindo sua constituição apenas a habilidades manipuladoras de probabilidades de prospecção e a uma capacidade de manipulação correta de regras e procedimentos formais de ambientes dotados de nítida redução de complexidade. A aplicação mecanicista dos procedimentos e conceitos cibernéticos à educação, por exemplo, acaba por reduzir a complexidade da aprendizagem, distinguindo indevidamente a dualidade sistêmica do nosso meio vital.

Devemos ter claro que quando houver a institucionalização de procedimentos que visam a reformulação de tipos de comportamento em ambientes sociais - utilizando ou não, para isso, os suportes digitais interativos de informação e comunicação -, não ocorrerá apenas uma nova

\footnotetext{
${ }^{17}$ Ver principalmente Luhmann (1997).
} 
modalidade normativa, mas também se acionarão novos papéis sociais e específicos que concorrem, ao mesmo tempo, com velhos comportamentos e papéis habituais. Ao optarmos por papéis e comportamentos socialmente concebíveis e possíveis, excluímos outros. Um sistema digital oferece, certamente, orientações comportamentais que facilitam a redução da complexidade, exonerando o ator ou agente da obrigação de fazer uma escolha entre as múltiplas alternativas possíveis. Porém, isso só será possível quando ele for uma expressão da própria "redução de complexidade vital".

O velho combatente do neopositivismo alemão, Jürgen Habermas, ressaltou dois problemas vinculados a essa interpretação de Luhmann da realidade: por um lado, o reducionismo simplificador entre realidade e sua representação; por outro, a dificuldade de captar as funções que assegurem a permanência do sistema quando este não apresenta redução de complexidade ou quando se desenvolve justamente em sentido contrário, aumentando a sua complexidade. ${ }^{18}$

A visão de tráfego probabilístico dos processos de informar e conhecer (implícita ou explicitamente) como solução típica da complexidade sistêmica digital transforma as relações e expressões sociais apenas em redutores de freqüências sociais, mas em expressões do condicionamento factual das ações, com grau muito restrito de liberdade. Os neopositivistas, ao quererem realizar uma pretensa redução dual entre a realidade e sua representação da cibernética social, tornam-se deterministas tecnológicos. Ao mesmo tempo, eles tentam resolver o problema num dualismo (real e virtual) que, pela simbiogênese, é um falso dualismo. Os neopostivistas pretendem "fundir" a realidade com a sua representação, na qual o real é considerado irreal e o simbólico é encapsulado por ambientes sistêmicos, tornando-se uma nova realidade "superiora", sem considerar as complexas mediações simbióticas, que retêm, num mesmo mundo, tanto aquilo que se pretende que seja "real" quanto "irreal", o lógico e o analógico. A solução desta cibernética social, inerente ao próprio conceito reducionista de sistema, tem, portanto, efeito conservador.

Essa grande confusão se faz presente também, de modo diferenciado e menos aparente, em Pierre Levy, nos "levianos" 19 e em muitos deterministas tecnológicos. E a ela deve-se a dificuldade de dotar de complexidade a grande revolução interfacial que a micro-computação abstrata promoveu. Pensamos que nesse ponto reside uma das principais dificuldades para os deterministas tecnológicos, ao buscarem entender o fenômeno do interfaciamento. Para nós, a cultura da interface digital, mesmo constituindo uma emergência revolucionária de suporte ao conhecimento reflexivo, refere-se muito mais a expressões e mediações redutoras da complexidade. Como já foi dito, essa confusão é o que faz com que espíritos impacientes criem crendices "científicas" pelos meios intelectuais, expandindo armadilhas e imprecisões entre os agentes reflexivos, alargando suas crenças reducionistas no dualismo entre vida social e ambientes sociais sistêmicos (fechados ou semi-abertos) ou entre o ser e a rede.

A sobreabstração induzida pela potente ação da computação abstrata, interfaciada pelos poderosos agenciamentos maquínicos/simbólicos atuais, torna quase invisível essa distinção, que passa como despercebida para muitos, ocorrendo o aprisionamento da representação digital da realidade e o encapsulamento do agente reflexivo, como aquele inseto que, logo após ser aprisionado nas armadilhas da rede feita pela aranha, é encasulado para servir de alimento.

Enfatizar a contraditória relação entre a realidade e as formas sistêmicas de representação sempre foi um dos papéis fundamentais da Sociologia e do conhecimento complexo. Tal assertiva é

\footnotetext{
${ }^{18}$ Ver principalmente Habermas (1968, 1987; 1988, p. 465-508; 2000).

${ }^{19}$ Seguidores do tecnólogo francês Pierre Levy.
} 
válida porque uma determinada modalidade de expectativa para captarmos a dinâmica da história deve ser encarada como, nada mais, nada menos, um redutor da complexidade vital. Caso contrário, mergulhamos num velho conservadorismo, mesmo que moldado por termos futuristas da ficção. Isso porque, por mais interativo que seja um sistema digital, por mais amplificadas que sejam as suas modalidades de compartilhamento com a realidade humana e vital de pensar sobre o mundo, e por mais que gere novas possibilidades e potencialidades de amplificações reflexivas, ele sempre será um redutor de complexidade, restringindo novas possibilidades de significação que não estejam vinculadas aos seus parâmetros e não possibilitando de imediato a implementação de outras normas e valores (recursos reflexivos) que possam ser estabelecidos, criados ou criticados de modo consensual ou não.

A teoria sistêmica, nesse sentido, não tem condições de explicar a forma como normas e procedimentos encapsulados autonomizam-se de valores que emergem junto ao sistema e passam a regulamentar as suas interações. Para admitir que essa contradição entre realidade sistêmica e a realidade vital aconteça, os neopositivistas deveriam abrir mão da categoria de sistema (ambiente digital) e poderiam, por exemplo, falar de rotinas interativas digitais esparsas ou abertas. Porém, isso não altera a perspectiva de haver interações de baixa constituição de significados na interação dialógica frente à constituição de significados previamente estabelecidos, que, por um lado, precisam ser internalizados pelos atores ou agentes para que possam se comportar de acordo com as orientações sugeridas; e, por outro, precisam institucionalizar-se em papéis previamente instituídos, mesmo que através de procedimentos de elevada reflexividade, pois, sem isso, não seria possível que eles tivessem validade social. Enfim, sem essa clareza na distinção (não separação) e na simbiose entre representação sistêmica da realidade e realidade vital, lembrando a formulação habermasiana, essa perspectiva se reduziria a apenas mais uma nova expressão da modalidade de colonização da racionalidade instrumental sobre o mundo da vida (HABERMAS, 1988, p. 465-508).

O conhecimento só pode emergir de modo emancipatório em situações dialógicas, em que ego e alter atribuam significado às coisas, às pessoas e às suas relações, de modo consensual ou não, e em situações em que seja respeitada a autoconstrução dos processos significantes, mesmo quando ocorram relações sociais sem rosto (não diretamente presenciais), as quais são cada vez mais importantes no mundo contemporâneo. Para que possa ocorrer essa emancipação reflexiva, é necessário haver um grau elevado de liberdade, inadmissível para a concepção sistêmica. Estamos convencidos de que o conceito de sistema/ambiente neopositivista e o conceito de informação complexa são incompatíveis em muitos aspectos.

A oscilação entre a distinção dualista; realidade vital e sistêmica-virtual e a indistinção simplificadora e a-simbiótica entre representação e realidade; a mecânica substituição do conceito de informação ou interação informacional pelo de conhecimento; a indistinção dual simplificada entre relações sociais com rosto e sem rosto e suas implicações para a construção do conhecimento complexo e, por fim, a definição prioritária da função sistêmica como "redução de complexidade" (ambiente/espaço de informação não simbiogênico) constituem muitos dos temas vulneráveis da teorização da nova modulação determinista de conhecimento sistêmico programável proveniente das tecnologias de informação computacional e que, independente disso, se alastra como praga por múltiplos campos do saber (LIMA, 2005, p. 244).

Como vimos, essas divergências têm, como pano de fundo, a diferenciação do entendimento da efetiva "revolução" das tecnologias informacionais no atual processo de aceleração tecnológica, em curso nas sociedades ocidentalizadas, o qual foi e está sendo muito dinamizado pelo tratamento da informação digital. Isso não nos obriga, de modo algum, a nos alinharmos aos conservadores, a estacionar o potencial reflexivo das novas relações emergentes promovidas 
pelas mediações com as tecnologias da informação e comunicação e a nos submetermos aos velhos hábitos da tradição e controle disciplinar das sociedades de baixa reflexividade. Ao contrário, não vemos outra possibilidade de imersão crítica no processo reflexivo se não partirmos, desde agora, para novas modulações institucionais que rompam com os velhos processos disciplinares dominantes do poder saber e de poder conhecer nas sociedades industriais.

Para nos libertarmos do saber disciplinar, não necessitamos da produção e aquisição de sistemas/ambientes de encapsulamento, mas sim da implantação de procedimentos e processos sociais, com ou sem rosto, que constituam e aprimorem efetivamente a emergência de uma nova cultura para acesso e construção do conhecimento reflexivo e complexo que incentive novos papéis de trocas e reflexividades em ambientes semipresenciais ou presenciais que (des) discipline, (des) asfixie o conhecimento, (des) controle e flexibilize suas estruturas de controle racional, permitindo que se possam emergir novos agenciamentos individuais e sociais. $\mathrm{O}$ sociólogo inglês Anthony Giddens chamou apropriadamente nossa atenção para a substituição da idéia de controle pela de monitoramento reflexivo. ${ }^{20}$ Necessitamos, ainda, potencializarmos a ampliação sensória da subjetividade, do lúdico, permitindo o crescimento afetivo/emocional e maduro da inteligência não-cognitiva (reflexividade estética, afetiva, sensória).

Uma perspectiva meramente fenomenológica das interações entre os redutores da complexidade seria satisfatória apenas em face dos fenômenos advindos da experiência primeira dessas interações, emergindo de um saber e um de agir pouco reflexivo. Uma perspectiva sistêmica não permite, sequer, darmos conta satisfatoriamente das novas subjetividades emergentes, que o tratamento digital da realidade potencializa. As próprias pesquisas sobre a identidade na rede digital indicam um caminho contrário, que é o de que as interações digitais, a partir da integração entre cultura e interface, permitem um alargamento da dobra subjetiva, uma expansão desterritorializada do(s) eu(s) e da realidade em rede com os outros, que podem, inclusive, possuir também múltiplos eus materializados por interações não-presenciais. ${ }^{21} \mathrm{~A}$ ação interativa, porém, não é somente uma combinação de "atos". Como escreve Giddens, os "atos" são constituídos apenas por um momento discursivo de atenção à durée da experiência vivida ( $a$ estratificação do self). Assim, a durée apresenta-se como a forma especificamente reflexiva da cognoscibilidade dos agentes humanos, que está mais profundamente envolvida com a ordenação recursiva das práticas sociais. A continuidade de práticas presume reflexividade, mas esta, por sua vez, só é possível devido a continuidade de práticas que as tornam nitidamente "as mesmas" através do espaço e do tempo (o que retém não apenas como registro físico ou algorítmico de memória). Logo, a "reflexividade" deve ser entendida não meramente como "autoconsciência", mas como o caráter monitorado do fluxo contínuo da vida social. Para Giddens, o ser humano é potencialmente um agente intencional que tem razões para suas atividades, estando também apto, se solicitado, a elaborar discursivamente essas razões - inclusive mentindo a respeito delas (GIDDENS, 1989, p. 52-58).

Em circunstâncias de interação - encontros e episódios -, a monitoração reflexiva da ação incorpora tipicamente, e uma vez mais, rotineiramente, a monitoração do cenário, onde essa interação desenrola-se, fenômeno que é básico para a interpolação da ação dentro das relações espaço-temporais daquilo que Giddens designa, parafraseando a fenomenologia, como "co-

\footnotetext{
${ }^{20}$ Giddens diz não à experiência do ator individual e não à existência de qualquer forma de totalidade social, mas sim às práticas sociais ordenadas no espaço e no tempo, nas quais as atividades sociais humanas são recursivas e continuamente recriadas por atores sociais ("cognoscitividade"). Ver Giddens (1989, p. 4-5).

${ }^{21}$ Ver principalmente Turkle (1997, 1989); Sherry Turkle é escritora e professora de sociologia da ciência no Instituto de Tecnologia de Massachussetts. Ver também Allucquère (1992).
} 
presença”. Na reflexividade da sociedade contemporânea, onde não mais podemos abarcar com nossas mãos e cérebros a mecânica totalidade social tão sonhada pelos modernos, a vivência da co-presença muito resulta em co-ausência, com rosto e sem rosto.

A monitoração reflexiva da ação, depende da complexidade da ação, está sendo entendida aqui mais como um processo do que como um estado funcional para o controle racional ou normativo do velho estruturalismo. Tanto o funcionalismo quanto o estruturalismo inclinam-se para o naturalismo e o objetivismo da estrutura, em muito anulando a autonomia do agenciamento individual e coletivo e a ação reflexiva dos agentes sociais.

Enfim, a simples idéia de criarmos sistemas ou de virarmos consumidores de encapsulamentos digitais (ambientes), nos quais todos possam ser submetidos aos seus procedimentos, configurase como uma tarefa tanto mais fácil quanto ineficaz, a longo prazo, diante da produção complexa de conhecimento em redes hipertextuais.

\section{Considerações finais}

Por fim, para concluirmos sobre esses desafios, gostaríamos de sugerir e reafirmar algumas considerações mais analíticas presentes explícita ou mais implicitamente nesse artigo. Como vimos, a informação computadorizada está conquistando, cada vez mais, um espaço de significação reflexiva, devido a sua potencialidade mediadora diante da realidade e, inclusive, diante da própria construção do saber.

A informação resignificada pela nova mídia reflexiva digital nos apresenta cada vez mais um resultado de pasteurização do mundo, realizada por mediações de estruturas semi-reflexivas, o que gera também, cada vez mais, uma complexa sintetização digital da realidade. Um desafio gradativamente maior sobre nossa capacidade analítica de continuarmos no difícil caminho da qualidade complexa da produção do conhecimento sociológico é aprendermos a escapar dos convenientes atalhos facilitadores, causados pelos encantamentos juvenis oferecidos pelo determinismo tecnológico, e também evitarmos o embotamento causado pela cegueira conservadora que pretende apenas uma reprodução da tradição escolástica, insistindo em não sair do final do Século XIX e das primeiras décadas do Século XX.

Assim, há uma questão importante a considerarmos: não se trata de uma pequena façanha humana realizarmos a replicação das atividades rotineiras do processamento lógico do "cérebro" humano em máquinas cognitivas e, também, não é insignificante a criação humana que permite amplificarmos nossas ressonâncias sensórias em sofisticados suportes ambientalizados por sistemas digitais de simulação e interação. Porém, não podemos concordar que a infra-estrutura reflexiva de informação e comunicação digital, mesmo sendo capaz de replicar, inclusive, uma reflexividade mimética (representação imitada), seja sinônimo de conhecimento complexo, ou de que ela em si mesma trate-se de uma nova modulação de conhecimento. A rede digital de comunicação e de informação computada não passa de uma mera invenção potente de redução de complexidade. ${ }^{22}$

\footnotetext{
${ }^{22}$ Como contraponto à perspectiva da compressão (não-compreensão) da modalidade do conhecimento e de conhecer, ver a sofisticada proposta de Edgar Morin, principalmente em Inteligência da complexidade (2000).
} 
Reafirmamos que, ao darmos conta de modo extremamente preciso da redução da complexidade da realidade vital, as novas tecnologias de informação e comunicação possibilitam, em contrapartida, uma gama quase infinita de amplificadores cognitivos a serem exercidos em simbiose do mundo vital com o mundo digital, facilitando extremamente a produção do conhecimento na sociedade contemporânea, na qual o próprio conhecimento pode, agora, ocupar efetivamente, na história de nossa civilização, um novo lugar na produção e reprodução das sociedades. Pensamos que compreender as redes digitais, não na dimensão do determinismo tecnológico que pretende encapsular o mundo e as relações em sistemas tecnológicos de informação, do mesmo modo com que a aranha encapsula suas presas nas redes, mas como uma complexa simbiose de atividades sociais de integrações, cooperações e conflitos, seria muito mais adequado do que instalar apenas fisicamente fibras óticas e computadores, aleatoriamente, pelo tecido social e societal.

É certo que, sem a dimensão física das redes (fibras, máquinas e softwares recursivos), não podemos dotar de complexidade o conhecimento junto ao novo suporte complexo da informação e da sua própria representação e reconstrução sobre a realidade física e social. Assim, as dimensões física e tecnológica das redes são determinantes, mas insuficientes, para migrarmos a cultura e o conhecimento civilizatório complexo acumulado para as novas mídias da informação, bem como, para produzir e reproduzir esse mesmo conhecimento, tanto na velocidade da sua produção e reprodução, quanto na qualidade e complexidade desejada pelos investigadores e produtores desse mesmo conhecimento complexo.

\section{Referências}

ALLUCQUÈRE, RS. Virtual system. In: CRACY, Jonathan; KWINTER, Sanford (Ed.). Incorporations. New York: Zone, 1992. (Zone 6).

BARABÃSI, A. Linked: the new science of networks. New York: Plume Books, 2002.

BARRY, Christine A. Choosing qualitative data analysis aoftware: atlas-ti and nudist Compared. Sociological Research Online, Guildford: University of Surrey, n. 3, Sept. 1998. Disponível em: <http://www.socresonline.org.uk/socresonline/3/3/4.html>. Acesso em: 24 set. 2005.

BOOLE, G. An investigation of the laws of thought. New York: Dover, 1958. 1. ed. 1854.

BRENTON, P. História da informática. São Paulo: Ed. Unesp, 1991.

BROCKMAN, J. O cético: Cliff Stoll. In: Digerati: encontros com a elite digital. Rio de Janeiro: Campus, 1997.

CAPRA, F. A teia da vida. São Paulo: Cultrix, 1998. p. 216.CARREIRAS, Ferran Tuduri. Metodologia de investigação em educação especial: a análise qualitativa de dados. 1997. <http://www.niee.ufrgs.br/Icieep/ponencias/dos-31.htm>. Acesso em: 24 set. 2005.

CEIRANO, Virginia; RODRÍGUEZ, Gustavo. Análise de discurso assistido por computador: nossa experiência com o NUD*IST. Disponível em: < http://www.analisiscualitativo.com.ar/analista.htm>. Acesso em 24 set. 2005 
FININ, Tim; MAYFIELD James; LABROU, Yannis. KIF101: a brief introduction to the knowledge interchange format. $U M B C$ AgentWeb. Disponível em: <www.cs.umbc.edu/kse/kif/kif101.shtml> Acesso em: 24 set. 2005.

FUNDAÇÃO DE ECONOMIA E ESTATÍSTICA. Disponível em: <http://www.fee.tche.br/sitefee/pt/content/capa/index.php>. Acesso em: 24 set. 2005.

GLADWELL. M. O ponto de desequilíbrio. Rio de Janeiro: Rocco, 2002.

GIDDENS, A. A constituição da sociedade. São Paulo: Martins Fontes, 1989.

HABERMAS, J. Conhecimento e interesse. Rio de Janeiro: Guanabara, 1987. . Discurso filosófico da Modernidade. São Paulo: Martins Fontes, 2000. . La lógica de las ciencias sociales. Madrid: Tecnos, 1988. . Técnica e ciência como ideologia. Lisboa: Edições 70, 1968.

IUPERJ. Programa Institutos Virtuais. Disponível em: <http://www.iuperj.br/>. Acesso em: 24 set. 2005.

JOHNSON, S. Emergência: a dinâmica de rede em formigas, cérebros, cidades e softwares. Rio de Janeiro: J. Zahar, 2003.

LÉVY, Pierre. As tecnologias da inteligência: o futuro do pensamento na era da informática. Rio de Janeiro: Ed. 34, 1993.

LIMA, Gilson. A reconstrução da realidade com a informação digital: a emergência da dupla competência sociológica. Porto Alegre, 2004. Tese (Doutorado em Sociologia) - Programa de Pós-Graduação em Sociologia da Universidade Federal do Rio Grande do Sul.

. Nômades de pedra: teoria da sociedade simbiogênica contada em prosas. Porto Alegre:

Escritos, 2005.

LOH, S.; GARIN, R. S. Web Intelligence: inteligência artificial para descoberta de conhecimento na web. Pelotas: Ed. da Universidade Federal de Pelotas, 2001.

LUHMANN, Niklas. A nova teoria dos sistemas. In: BAETA, Clarissa Eckert; SAMIOS, Eva Machado Barbosa (Org.). Niklas Luhmann: a nova teoria dos sistemas. Porto Alegre: Ed. UFRGS: Goethe Institut/ICBA, 1997.

MCLUHAN, M. A galáxia de Gutenberg. São Paulo: Cultrix, 1972.

MERLEAU-Ponty, M. La philosophe et la sociologie. Paris: Galimard, 1960, p. 136-137. (Collection Idées).

MORIN, Edgar. Ciência com consciência. Rio de Janeiro: Bertrand Brasil, 2000a.

. Inteligência da complexidade. Rio de Janeiro: Fundação Peirópolis, 2000 b.

_. O método 3: o conhecimento do conhecimento. Portugal: Europa-América 1990. 
NEGROPONTE, Nicolas. L’homme numérique. Paris: Fayard, 1995.

PRANDI, José Reginaldo. História de vida computacional. São Paulo: Cebrap, 1972.

RIFKIN, Jeremy. O século da biotecnologia: a valorização dos genes e a reconstrução do mundo. São Paulo: Makron Books, 1999.

RIVERA, E. R.; TRIGUEROS, C.; CAMACHO, M. M. O. Yo integro, tu incluyes, nosotros...un recto difícil. Lecturas: EF y deportes: revista digital, Buenos Aires, ano 5, n. 28, dic. 2000. Disponível em: <http://www.efdeportes.com/efd28/integr.htm>. Acesso: 24 set. 2005.

SIGKDD EXPLORATIONS. New York: Association for Computing Machinery, v. 1, n. 2, Jan. 2000. Disponível em: <www.acm.org/sigkdd/explorations>. Acesso em: 24 set. 2005.

SILVEIRA. Sidnei Renato; BARONE, Dante Augusto Couto. Modelando comportamento inteligente com algoritmos genético. In: BARONE, Dante (Org.). Sociedades artificiais: a nova inteligência nas máquinas. Porto Alegre: Bokman, 2003.

TAVARES DOS SANTOS, José Vicente. As possibilidades das metodologias informacionais nas práticas sociológicas por um novo padrão de trabalho para os sociólogos do século XXI. Sociologias, Porto Alegre, n. 5. p.114-146, 2001.

TURKLE, Sherry. A vida no ecrã: a identidade na era digital da Internet.. Lisboa: Relógio D' água, 1997.

.O segundo eu: os computadores e o espírito humano. Lisboa: Presença, 1989.

UNICAMP. Portal das Ciências Sociais e Sociedade da Informação. Disponível em: < http://www.bibli.fae.unicamp.br/hz144/portal.htm>. Acesso em: 24 set. 2005.

UNIVERSIDADE FEDERAL DE MINAS GERAIS. Centro de Estudos de Criminalidade e Segurança Pública. Disponível em: <http://www.crisp.ufmg.br/>. Acesso em: 24 set. 2005.

WEBER, Max. A "objetividade" do conhecimento nas ciências sociais. In: COHN, Gabriel (Org.). Weber. São Paulo: Ática, 1991. (Coleção Grandes Cientistas Sociais).

WINOGRAD, Terry; FLORES, Fernando. Understanding computers and cognition. Nova York: Addison-Wesley, 1991. p.107.

ZOHAR, D. O ser quântico. São Paulo: Best-Seller, 1996. 